ンより流出しドレーン抜去の時期が遅れ，患者が歩行 可能となった折に水封ビンとの間を鉗子などで閉塞し なければならないなどその取り扱いが一般人には若干 難しい。一方このような胸腔内ドレーンチューブを挿 入する目的としては術野より胸腔内に流れ込んだ出血 を導くこともさることながら，開胸側の脱気が第 1 の ものである．臓側胸膜を損傷していない手術すなわち 肺実質よりの空気漏出がない場合ならば当初の脱気さ 完壁であればその後に気胸をみることはないわけで ある。

このような理由から，われわれは壁側胸膜を損傷し た時に開孔部より高圧吸引 バック（HEMOVAC® ま たは Relia Vac®) に付属する1/8インチのチューブ を挿入し，壁側胸膜開孔部は放置したまま手術を終え た. 50 例の漏斗胸手術の開胸例に対して高圧吸引ドレ ナージを施行したが術直後の胸部レントゲン写真にて ほとんどの症例は肺の拡張は十分であった。 また若干 の気胸を残した症例も術後 2 日目には気胸を認めなか った．ごく少数に胸膜を高圧吸引することに起因する と考えられる疼痛をみた以外，本法はこのような場合 の胸腔ドレナージとして適した方法として勧められ る.

\title{
64. 各種高圧吸引バッグの比較検討
}

\section{東京女子医大 胸部外科 \\ 山口明満 中島秀嘼 横山正義 三栄測器森}

田中正彦

外科領域に扔いては, 術後排液の目的でドレーンチ ューブを挿入してくることが必須の条件である，その 際, 各施設により各種の高圧吸引バッグが用いられて いる。しかし高圧吸引バッグす心゙てがその形状, 用 途，陰圧のかけ方，陰圧值などにおいて同一規格では ない，われわれは右外科領域において用途にあった高 圧吸引バッグを選択すべきであるといら方針により， 今回現在入手し得る 6 種の高圧吸引バッグを使用し排 液量と㓌圧の関倸につき実験を行った，使用した高圧

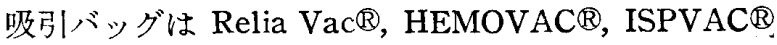

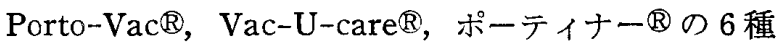
である．実験方法は各高圧吸引バッグ使用法手順どお りに空の状態で陰圧にし，トランスデューサ（東洋ボ ルドウィン社製 MPU-0.5-290-O-II) を接続し, 水
道水を $100 \mathrm{~m} l$ ずつ $500 \mathrm{~m} l$ まで注入し，おのおのの圧 測定を行い，三栄測器製横型 ポリグラフ $120 \mathrm{~A}$ (血圧 用増幅器1236）にて記録を行った。実験結果は, どの 注入量においても，もっとも強い陰圧を示したのは Relia Vac®，で，陰圧が最後までほとんど変化しなか ったのが，Vac-U-care® とISPVAC®であった。 わ れわれはこの実験が，これから高圧吸引バッグを選択 しょらとしている方がたにとり，少しでも参考になれ ばと考えている。

\section{5. 肝臓外科における超音波メスの評価}

東京慈恵医大 第 1 外科

竹村隆夫 河井啓三 又井一雄翁伯 東 富沢誠 小林進 町田崇岡部紀正 桜井健司

超音波メスは，いわゆる超音波振動の作用を利用 し，チップ先端に触れる組織を乳化，細分化し，術野 外一吸引排除する装置であり, 近年, 脳外科去よび肝 切除の外科括いて有用視されている。 しかし肝切除 後の残存肝組織に与える傷害の程度, その切断部の再 生などについては十分な検討がなされていない．

われわれは健常なイエウサギの肝臟を超音波メスで 切除し, その断端部の組織変化を経時的に検索し,さ らに VX2 癌を肝臟に 移植したウサギを用い，覀性腫 湯に対する超音波メスの効果についても検討を加えた ので報告する.

[対象ならびに方法]実験動物として成熟したイエ ウサギを選び, 静脈麻酔下で開腹し, 超音波メス装置 を用いて肝部分切除を行った。使用した装置は，持田 製薬製のソノテック（Model-MAA-2511）である. 本 装置の最高出力は $100 \mathrm{~W}$ ， 発振する超音波の周波数は $24 \mathrm{kHz}$ であり，ホーン先端を対象部位に密着させて使 用する，ウ市代の肝切除には50W出力の超音波を用い た. この出力で用いると肝実質の乳化は瞬時に行われ るが，血管・胆管などの線維性組織が温存されほとん ぞ無血的な切除が可能であった。肝切除断端部の組織 学的変化は，H-E 染色により経時的に検索した。 ま た VX2 癌移植肝に対しては超音波メスの刺激による 局所再発能ならびに全身性転移の程度を観察した。

[研究結果]肝切除直後の切断端をみると, 超音波 による細胞破壊と熱性変化に伴う狭い範囲の細胞変性 帯が認められた。この断端の変化を経時的に観察する 